\title{
39. EVALUATION OF PHYSICAL PROPERTIES MEASUREMENTS
}

\author{
Jennifer M. Lort, Department of Geodesy and Geophysics, University of Cambridge, Cambridge, England
}

\section{INTRODUCTION}

After measuring physical properties of cores on board during Leg 13 , I shall try to assess the reliability that may be placed on the values obtained, and the degree of error involved in interpretation. The methods employed include the penetrometer, natural gamma radiation, and methods to measure density, porosity, and water content.

\section{PENETROMETER READINGS}

Penetrometer readings are a measure of sample induration. Reproducible results are not always obtained. The height at which the needle is placed above the surface of the sediment seems to be critical; a difference of a millimeter between successive levels can cause a discrepancy of up to 20 in the values obtained. If the needle touches the sediment, the readings are reduced relative to their true value; if the needle is too high, the readings are also high. Thus the factor of personal error is large.

Disturbance in cores can cause great variation in readings within a supposedly uniform area of the section. Voids and cracks due to drilling or degassing, slumping, and watery deformation all affect the values obtained, so that measurements are only meaningful in the most homogeneous and unaffected cores. In sediments showing the slightest degree of thixotropy, there are also changes due to disturbance, both from successive measurements and ship vibration.

\section{NATURAL GAMMA RADIATION}

Natural gamma radiation measures the total count rate rather than giving a spectral analysis of the individual isotopes, which would provide more information about lithology. At present, the counts are digitized and recorded at intervals of $7.5 \mathrm{~cm}$; extrapolation between readings is not always valid. It does seem, however, that determinations of radiation, even on cores showing up to 50 per cent voids, are meaningful.

Reproducibility is satisfactory, and there is no apparent deterioration on a second, third, or even fourth run of a single core. The system is calibrated to count the background rate on standards of air and water. When the standard deviation was calculated for repeated measurements in a single core, and also for the count rate in the standards, it was seen that they are approximately equal.

The standard deviations are:

$\begin{array}{ll}\text { Air } & =36.73 \\ \text { Water } & =44.97 \\ \text { Sediments of Site 132, Core 20-4-的 } & =46.82 \\ \sigma_{2} & =47.82 \\ \sigma_{3} & =44.25\end{array}$

\section{BULK-POROSITY AND BULK-DENSITY}

$\mathrm{V}_{\mathrm{f}} \quad=$ Volume of interstitial water (sample)

$V_{t}=$ Total volume of wet sediment (sample)

$\mathrm{V}_{\mathrm{t}, \mathrm{s}, \mathrm{s}}=$ Volume of plastic liner of a core-section

$\mathrm{W}_{\mathrm{t}}^{\mathrm{c.s.}}=$ Total weight of wet sediment (sample)

$\mathrm{W}_{\mathrm{s}}=$ Weight of dry solid (sample)

$\mathrm{W}_{\mathrm{f}}^{\mathrm{s}}=$ Weight of interstitial liquid (sample)

$\mathrm{W}_{\mathrm{c} . \mathrm{s} .}=$ Weight of core section

$\rho_{\mathrm{b}}^{\mathrm{c.s} .}=$ Bulk density

$\rho_{\mathrm{g}}=$ Grain density

$\rho_{\mathrm{f}} \quad=$ Density of interstitial brine

$\rho_{\mathrm{w}}=$ Density of water

$\phi \quad=$ Porosity

Two methods were employed on board to determine the porosity and bulk density of samples. They were by weighing and by the GRAPE, or gamma-ray attenuation method. The average grain density of the samples could then be computed by the relations:

$$
\rho_{\mathrm{g}}=\rho_{\mathrm{b}} \phi+\rho_{\mathrm{f}}(1-\phi) .
$$

The density of the interstitial brine has been assumed to be $1.03 \mathrm{~g} / \mathrm{cm}^{3}$; the error introduced by such an assumption is negligible.

\section{Determinations by Weighing}

Porosity of individual samples was determined by the relation

$$
\phi=\frac{\mathrm{V}_{\mathrm{f}}}{\mathrm{V}_{\mathrm{t}}}
$$

The volume of the wet sediment was determined by the size of the sample container. The volume of the interstitial water was determined by weighing the water loss after desiccation, or

$$
\mathrm{V}_{\mathrm{f}}=\rho_{\mathrm{w}}\left(\mathrm{W}_{\mathrm{t}}-\mathrm{W}_{\mathrm{s}}\right) .
$$

Water content is defined by the ratio $\mathrm{W}_{\mathrm{f}} / \mathrm{W}_{\mathrm{s}}$, and is expressed as a percentage without salt correction.

Bulk density was determined by the relation

$$
\rho_{\mathrm{b}}=\frac{\mathrm{W}_{\text {c.s. }}}{\mathrm{V}_{\text {c.s. }}}
$$

assuming that core sections have been cut to their proper standard length of 1.5 meters, and that the liners were completely filled by wet sediment. 
However, the liners were frequently cut to lengths different than that of the standard. Also, the wet sediment within a plastic liner might be mixed with sea water, drilling slurries, or dissolved gases. Such mixtures tend to give a bulk density value lower than the true value.

\section{Determination by GRAPE}

The GRAPE system continuously measures the variation in density, porosity, and water content, and records these on a strip chart. It is calibrated relative to a set of standards.

$\begin{array}{ll}\text { Density of aluminum (true) } & 2.60 \\ \text { Density of aluminum (standard) } & 2.60 \\ \text { Density of water (true) } & 1.024 \\ \text { Density of water (standard) } & 1.121\end{array}$

During this cruise, it was found that the calibration was inaccurate, as suggested by a systematized discrepancy between computed values of bulk density and porosity from the GRAPE and those calculated by the weighing method (Table 1). The calibrated standard deviations are shown in Figure 1.

Commonly, the GRAPE readings gave too high a value so that the grain density and porosity values computed from GRAPE data also tended to be too high. For example, at Site 132, the following values were recorded:
a) Core 3 Section $2-3.081 \mathrm{gm} / \mathrm{cc}$
b) Core 4 Section $6-3.042 \mathrm{gm} / \mathrm{cc}$
c) Core 5 Section $1-4.394 \mathrm{gm} / \mathrm{cc}$
d) Core 6 Section $3-3.086 \mathrm{gm} / \mathrm{cc}$
e) Core 9 Section $6-3.060 \mathrm{gm} / \mathrm{cc}$
f) Core 19 Section $1-3.023 \mathrm{gm} / \mathrm{cc}$

These grain density values are much too high to be realistic, although the presence of a pyrite nodule in Sample 132-3-2 may account in part for the abnormally high average grain density.

\section{RANGE OF GRAIN DENSITY}

For a pure calcite sediment, the grain density should be $2.71 \mathrm{~g} / \mathrm{cm}^{3}$. The presence of quartz $\left(\rho_{\mathrm{g}}=2.65 \mathrm{~g} / \mathrm{cm}^{3}\right)$, muscovite $\left(\rho_{\mathrm{g}}=2.76 \mathrm{~g} / \mathrm{cm}^{3}\right)$, or clay minerals $\left(\rho_{\mathrm{g}}=2.1-2.6\right.$ $\mathrm{g} / \mathrm{cm}^{3}$ ) would tend to cause a deviation of the average grain density from 2.71 .

TABLE 1

Site 127

\begin{tabular}{|c|c|c|c|c|c|c|}
\hline \multirow[b]{2}{*}{ Core } & \multicolumn{2}{|c|}{ Bulk Density $\left(\rho_{\mathrm{b}}\right)$} & \multicolumn{2}{|c|}{ Porosity $(\phi) \%$} & \multicolumn{2}{|c|}{ Grain Density $\left(\rho_{\mathrm{g}}\right)$} \\
\hline & $\begin{array}{l}\text { Weighing } \\
\text { Method }\end{array}$ & GRAPE & $\begin{array}{l}\text { Weighing } \\
\text { Method }\end{array}$ & GRAPE & $\begin{array}{l}\text { Weighing } \\
\text { Method }\end{array}$ & GRAPE \\
\hline 1 & $\begin{array}{l}1.67 \\
1.60 \\
1.70\end{array}$ & $\begin{array}{l}1.70 \\
1.74 \\
1.75\end{array}$ & $\begin{array}{l}44.8 \\
40.2 \\
51.0\end{array}$ & $\begin{array}{l}60 \\
58 \\
56\end{array}$ & $\begin{array}{l}2.21 \\
2.00 \\
2.43\end{array}$ & $\begin{array}{l}2.75 \\
2.78 \\
2.70\end{array}$ \\
\hline 2 & $\begin{array}{l}1.76 \\
1.85\end{array}$ & $\begin{array}{l}1.75 \\
1.80\end{array}$ & $\begin{array}{l}50.8 \\
46.1\end{array}$ & $\begin{array}{l}56 \\
52\end{array}$ & $\begin{array}{l}2.54 \\
2.58\end{array}$ & $\begin{array}{l}2.70 \\
2.72\end{array}$ \\
\hline 7 & $\begin{array}{l}1.75 \\
1.81\end{array}$ & $\begin{array}{l}1.75 \\
1.80\end{array}$ & $\begin{array}{l}42.4 \\
43.3\end{array}$ & $\begin{array}{l}58 \\
55\end{array}$ & $\begin{array}{l}2.29 \\
2.58\end{array}$ & $\begin{array}{l}2.78 \\
2.78\end{array}$ \\
\hline 10 & $\begin{array}{l}1.81 \\
1.83\end{array}$ & $\begin{array}{l}1.90 \\
1.95\end{array}$ & $\begin{array}{l}43.2 \\
43.6\end{array}$ & $\begin{array}{l}48 \\
44\end{array}$ & $\begin{array}{l}2.43 \\
2.48\end{array}$ & $\begin{array}{l}2.73 \\
2.70\end{array}$ \\
\hline 14 & $\begin{array}{l}1.52 \\
2.00 \\
1.73\end{array}$ & $\begin{array}{l}1.65 \\
2.00 \\
1.75\end{array}$ & $\begin{array}{l}36.9 \\
38.8 \\
42.9\end{array}$ & $\begin{array}{l}60 \\
42 \\
56\end{array}$ & $\begin{array}{l}1.82 \\
2.63 \\
2.28\end{array}$ & $\begin{array}{l}2.63 \\
2.63 \\
2.70\end{array}$ \\
\hline
\end{tabular}

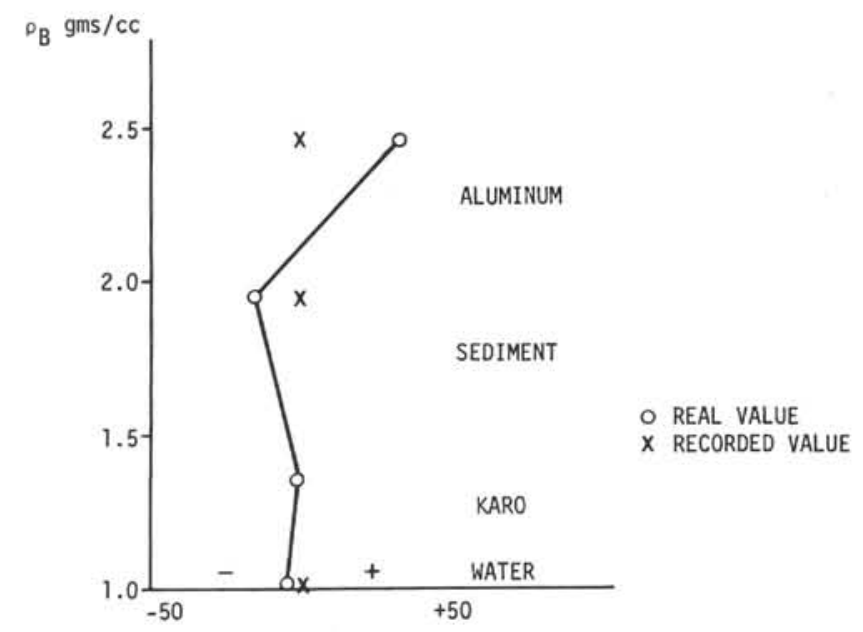

Figure 1. Standard deviation of density of GRAPE $\odot=$ real value and $X=$ recorded value.

Although clay-size particles are common in the sediments recovered, the clay mineral content is not high in all samples. The presence of appreciable clay minerals in certain samples, however, has resulted in low grain density for some samples. Table 1 shows the ranges of grain density values computed, as determined by both computational methods, for a number of Site 127 samples. The computed GRAPE values are near $2.71 \mathrm{~g} / \mathrm{cm}^{3}$. However, if the per cent of clay minerals is taken into consideration, the theoretically computed average grain density values should be lower than those given by GRAPE.

\section{CORRELATION OF PHYSICAL PROPERTIES AND LITHOLOGIES}

The general lithologies obtained from holes during this leg include nanno to marl oozes with interbedded sands, silts, sapropels and tephra horizons. Anhydrite, gypsum, and occasional limestone or dolomite fragments were also recovered. The physical properties measured suitably define this suite of rocks.

As already described, densities seem to be consistently low, when compared with values obtained on previous legs. The ranges are $\rho_{\mathrm{b}}: 1.6$ to $1.8 \mathrm{gm} / \mathrm{cc}$, and $\rho_{\mathrm{g}}: 1.9$ to 2.5 with rare high values of 2.0 to $2.8 \mathrm{gm} / \mathrm{cc}$. The higher grain densities do not seem to correspond to higher calcium carbonate content. Densities computed from section weights vary greatly in their accuracy, and are dependent upon the amount of voids present and the extent of disturbance. GRAPE records seem to show a series of values consistently higher than those determined from laboratory weighing.

There is a noticeable inverse correlation of density with porosity. The range of the latter is 60 to 40 per cent; the normal variation within one hole being 10 per cent. Water content similarly varies by 10 per cent in the range of 40 to 20 per cent. Both porosity and water content decrease with depth.

Penetrometer measurements show a decrease towards the bottom of the hole, and readings generally fall in the range 20 to 160 . Occasional extreme values occur (greater than 200 and less than 10), but it is doubtful how much 
reliance may be placed on their accuracy. This method cannot be used to assess induration in disturbed cores, since such distorted or "soupy" cores, represented by 'D' or 'W' in lithological descriptions (see also Notes on Disturbed Cores-Leg 13) produce anomalously high readings. Variation between sequences of multi-colored clays is often seen within single sections, while grading from coarse- to fine-grained beds will be accompanied by an increase in the values obtained. These coarse sands give high readings which are not too reliable when compared with those in finer silt horizons.

Natural gamma radiation measurements vary between 2000 and 3500 counts in the oozes, although the range may also extend to 1500 and 4000 counts in extreme cases. A marked decrease in counts is noticed with increase in calcium carbonate content, for example, 500 counts for a change of 20 per cent. This occurs in calcareous beds or local layers rich in foraminifera. Marl oozes show a higher range of counts than nanno oozes by about 200 counts. There also appears to be a decrease in natural gamma radiation with depth (see Site 130 report). Sapropel beds, high in organic content, and hence in absorbed radioactive minerals, give count rates up to and greater than 4000 , the average reading being about 3000 . Sand beds, rich in radioactive minerals, also show increased counts of between 2800 and 3500 above the background count rate in oozes, so that individual horizons may be identified from the graphic plots. Dolomites and anhydrite dolomites in all holes give high gamma-ray counts. 